Milica Tapavički-Ilić

Arheološki institut, Beograd

mtapavic@sbb.rs

UDK 904:725.73(497.11)"02/03"

Izvorni naučni članak

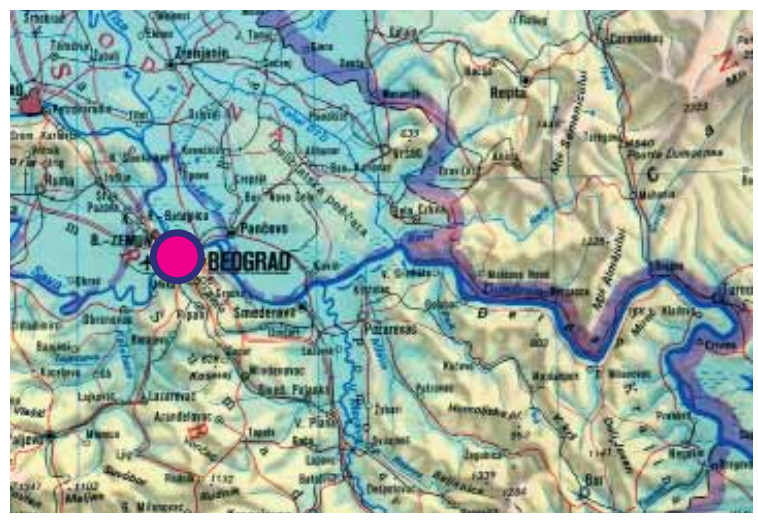

Singidunum, Beograd, Srbija

LAT $44^{\circ} 48^{\prime} 58^{\prime \prime} /$ LONG $20^{\circ} 27^{\prime} 56^{\prime \prime}$

\title{
PRILOG OPREDELJIVANJU RIMSKIH GRAĐEVINSKIH OSTATAKA SA LOKALITETA KOSANČIĆEV VENAC 12-16 U BEOGRADU
}

\begin{abstract}
APSTRAKT
Током ископавања локалитета у улиии Косанчићев венаи 12-16 у Београду откривени су остаци грађевине из римског периода. С обзиром да је истраживањима био обухваћен само иентрални део ове грађевине, било је тешко одредити њену намену. Ипак, у близини овог локалитета, у дворишту данашње Патријариије, откривен је натпис, на којем се спомиње римско купатило, терме. Њих је за своје саборие из легије IV Флавије подигао известан Елије Териије. Опис купатила које је овај ветеран изградио, а који се налази на споменутом натпису, у великој мери се подудара са резултатима добијеним током ископавања (базен, мозаиии). Због тога се може претпоставити да се на поменутој локаиији заиста налазило римско купатило коришћено у 3. и 4. веку.
\end{abstract}

\section{KLJUČNE REČI: KosanČIĆEV VENAC, RIMSKE GRAĐEVINE, BEOGRAD}

U periodu od 1989. do 1997. godine na lokalitetu Kosančićev venac 12-16 u Beogradu vršena su iskopavanja usmerena na istraživanja rimskih arhitektonskih ostataka. S obzirom da se otvaranjem otkopne površine naišlo na središte rimskog objekta i da nije konstatovan ni jedan od njegovih spoljnih zidova, ostalo je otvoreno pitanje da li se radi o luksuznoj građevini tj. vili ili kupatilu. ${ }^{1}$

Godine 1952. Miroslav Marković objavio je prevod i tumačenje natpisa nađenog u blizini zgrade Patrijaršije, stotinak metara udaljene od

1 Osnova otkrivenog dela ovog objekta objavljena je u članku Tapavički 1998, 121, pl. 2. lokaliteta na Kosančićevom vencu. ${ }^{2}$ Prevod će ovde biti naveden u celini: ${ }^{3}$

Ja, bistra voda, hraniteljka kupatila, padam sa [obližnje]

stene, pa je [tako] od kamena načinjen jedan divan [bazen ili ku-

patilo] i na živopisnom mestu niklo je jedno [veštačko] jezero.

Međutim, [sve je to] jedan suprug, povodom svog spasenja,

2 Марковић 1952, 234-240.

3 Marković 1952, 234. 
namenio na upotrebu upravo negdašnjim isluženim vojnicima

(veteranima) [legije (ili kohorte)], dostojne [da nosi] Aleksandrovo ime.

Sa stenovitog vrela pada bistra voda, potmulo žuboreći.

Vlasnik i tvorac ove, hvale toliko dostojne konstrukcije,

[jedan veteran?], zaželeo je da je posveti uspomeni na svoju

suprugu. Ipak, da bi i ti, čitaoče, mogao da doznaš (njegovo)

ime, kazuje [ti ga] svako pojedinačno početno slovo [stiha].

[Elije Tercije] sa Elijom Tercijom, ćerkom [ove] časne supruge.

Marković ovaj natpis datuje u vreme vladavine Aleksandra Severa, dok graditelja tj. donatora smatra veteranom legije IV Flavije. ${ }^{4}$ Ovo datovanje se poklapa sa datovanjem većine numizmatičkih i drugih sitnih nalaza sa lokaliteta, koji se opredeljuju u period 3. i 4. veka. ${ }^{5}$

Međunumizmatičkimmaterijalom nađenim od 1995. do 1997. preovlađuju bronzani novčići, a samo dva su izrađena od srebra. ${ }^{6}$ Većina pripada periodu vladavine vojničkih careva, od 235 . do 284. godine. U ranijim kampanjama je među rimskim numizmatičkim materijalom preovlađivao novac iz 4. veka (Valentinijan, Valens, Konstancije II), ${ }^{7}$ što je logično, jer su tada istraživani mlađi slojevi nalazišta.

Sitni nalazi iz kampanja od 1995. do 1997. obuhvataju dve aplikacije od bronzanog lima, Tfibulu, bronzanu narukvicu i prsten, kao i balsamarijum i žižak. Među nalazima iz ranijih kampanja takođe se nalazi jedna T-fibula, fragmenti tera-sigilate iz 2. i 3. veka, metalni delovi pojasa itd.

Posebnu pažnju privlače opeke sa žigom legije IV Flavije. One su nalažene tokom svih kampanja i rečito govore o tome da je vojska uzela učešće u izgradnji objekta o kojem je ovde reč.

4 Marković 1952, 238.

5 Тапавички 1998, 123.

6 Tapavički 1998-a, 54-62. Podaci se odnose na numizmatičke nalaze otkrivene tokom kampanja 1995, 1996 i 1997.

7 Цветковић-Томашевић 1981, 185, 189, 191, 195.
Dobar primer predstavljaju stubovi hipokausta, koji se sastoje od po osam opeka - sedam manjih i jedne veće, koja je služila kao baza stuba. Svaka od tih većih opeka na sebi ima žig LEG IIII FF (Legio IIII Flavia Felix). ${ }^{8}$ Ovakva formula imena legije navedena na pečatu spada među najstarije, tj. one korišćene krajem 1. i početkom 2. veka. U tom periodu je ova legija stacionirana na Dunavu, najpre u Viminacijumu, a zatim u Singidunumu. Dolazak IV Flavije u Singidunum se vezuje za završetak ratnih operacija protiv Dačana, tj. za period Trajanove vladavine.

$\mathrm{Na}$ osnovu formule pečata su opeke, a samim tim i građevina, datovani u kraj 1. i početak 2. veka. ${ }^{9}$ Ako bi se pošlo od pretpostavke da se ovde ipak radi o kupatilu, moguće je da je donator iskoristio već postojeću građevinu, kojoj je dodao bazen pravougaonog oblika, dimenzija 8,60 X 3,10 m, koji se na severnoj strani završavao polukružnom apsidom i do kojeg su sa istočne strane vodili kanali popločani kamenom. ${ }^{10}$ Položaj i pravac ovih kanala odgovarao bi opisu u redovima 1-2 i 8 Markovićevog prevoda. Po dimenzijama, bazen bi mogao odgovarati opisu iz trećeg reda istog. Zapadno od bazena nalazi se pravougaono dvorište, oko kojeg su sa južne i zapadne strane raspoređene prostorije zagrevane sistemom hipokausta. Površina severno od dvorišta nije u potpunosti istražena, ali su se i ovde, u istraženom delu, pojavili stubići hipokausta. Ova činjenica bi mogla da ukazuje na to da je dvorište sa tri strane bilo okruženo zatvorenim prostorijama koje su posedovale sistem zagrevanja, dok je sa četvrte, istočne strane, imalo izlaz ka bazenu. Pretpostavci da je donator, Elije Tercije, već postojećoj građevini dodao bazen i pretvorio je u kupatilo, ide u prilog činjenica da se u natpisu nigde ne spominju propratne prostorije, sastavni delovi svakog kupatila, već samo bazen.

Imajući u vidu carske terme, kao što su Trajanove ili Dioklecijanove u Rimu, ili pak čuvene terme u Triru, jasno je da bi se ovde radilo o jednoj vrlo pojednostavljenoj šemi kupatila tipičnih za period 2. i 3. veka. ${ }^{11}$ Ona su po strukturi prilagođena terenu i klimi u kojoj su nastajala, a

8 Цветковић-Томашевић 1981,183;

Тапавички 1998, 122.

9 Тапавички 1998, 122, nap. 5.

10 Тапавички 1998, 121, pl. 2.

11 Picard 1988, 146. 
po veličini potrebama stanovništva. U ostalom, na natpisu koji je donator postavio, najverovatnije na ulaz ovog kompleksa, stoji da je on kupatilo namenio na upotrebu negdašnjim isluženim vojnicima tj. veteranima legije u kojoj je sigurno nekada i sam služio (uporedi redove 5-7 Markovićevog prevoda). Moguće je da je pristup kupatilu bio omogućen samo relativno ograničenom broju korisnika, što i Marković potvrđuje u svom članku. On piše: ,...priroda je živopisna i bazen (ili kupatilo) je sjajno sagrađen, ali ipak, to nije svima namenjeno, već upravo (glavom), tim i tim veteranima...". ${ }^{12}$

Kao dekorativni element velikog broja termi javlja se mozaik. ${ }^{13} \mathrm{Ni}$ kupatilo sa lokaliteta na Kosančićevom vencu u tom smislu ne bi predstavljalo izuzetak. Otkriven je veliki broj ostataka podnih mozaika, njih preko 120 , rađenih od ulomaka crne, bele i crvene boje. ${ }^{14}$ Analizom nađenih fragmenata mozaika moglo se utvrditi da su primenjivane dve tehnike izrade: ,terrazzo“ i ,opus tessellatum“. Prva tehnika podrazumeva umetanje nepravilnih komada mermera i kamena u malter, dok druga podrazumeva ulaganje kockica od mermera i kamena u malter po određenom redosledu. Ustanovljeno je da se na 12 fragmenata ove tehnike javljaju u kombinaciji jedna sa drugom. ${ }^{15}$

Od fragmenata na kojima je bilo moguće utvrditi ukras, petnaest ima geometrijske motive, tri biljne, a dva figuralne. Među geometrijskim motivima se izdvajaju srcoliki motivi sa volutama, izvedeni crnim kockicama na beloj osnovi. ${ }^{16}$ Floralni motivi prikazuju stilizovane lotosove cvetove i pupoljke, takođe izvedene crnim kockicama na beloj osnovi. ${ }^{17}$ Najteže je bilo rekonstruisati fragmente sa figuralnom predstavom, za koje se pretpostavlja da predstavljaju zadnje noge neke životinje, zeca ili psa. ${ }^{18}$

Kombinacija dveju mozaičkih tehnika, od kojih je tehnika „terrazzo" starija, kao i činjenica da je čitav mozaik izveden u samo tri boje, govore $\mathrm{u}$ prilog ranom datovanju mozaika, a samim tim $\mathrm{i}$ cele građevine. Paralele za ovakve mozaike pos-

12 Марковић 1952, 237.

13 Picard 1988, 146.

14 Цветковић-Томашевић 1981, 180.

15 Цветковић-Томашевић 1981, 180.

16 Цветковић-Томашевић 1981, 181, sl. 8.

17 Цветковић-Томашевић 1981, 181, sl. 9.

18 Цветковић-Томашевић 1981, 181, sl. 10. toje u Galiji, npr. u Remsu. ${ }^{19}$ To bi možda moglo i da ukazuje na sastav legije IV Flavije, u kojoj je sigurno bilo dosta vojnika regrutovanih upravo iz ove provincije.

Među šutom nađeno je i dosta fragmenata zidnih fresaka. Većina je oslikana crvenom bojom, dok su ostali oslikani zelenom, oker i mrkom bojom. Na jednom fragmentu su crvenom, zelenom i crnom bojom oslikani koncentrični krugovi na beloj osnovi. ${ }^{20}$ Jedan fragment freske bio je pozlaćen.

Još jednu zanimljivost među pokretnim nalazima predstavlja osmougaona podna opeka. ${ }^{21}$ Ona je nađena u sondi br. VIII, u severozapadnom delu lokaliteta, dakle u onom u kojem je nađen najveći broj stubova hipokausta i najbolje očuvani delovi podnica. Ovakve opeke su u velikom broju nalažene na Viminaciujumu, i to upravo u termama.

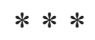

Iako bi napred navedeni argumenti mogli da potkrepe mišljenje da se kod rimskih građevinskih ostataka sa Kosančićevog venca radi o kupatilu, ipak treba zadržati izvesnu rezervu po tom pitanju. Udaljenost od oko sto metara između ostataka ove građevine i zgrade Patrijaršije, pored koje je natpis nađen, može se smatrati kako prevelikom, tako i adekvatnom, ako bi se uzelo u obzir da je natpis stajao na ulazu u park koji je okruživao kupatilo. Sa druge strane, već je ranije navedeno da je ovaj teren više puta nestručno prekopavan ${ }^{22}$, pa je sasvim moguće da su detalji, koji bi mogli da budu od presudne važnosti za opredeljivanje građevine, izostali. Tumačenje ovog natpisa i njegovo dovođenje u vezu sa obližnjim rimskim arhitektonskim ostacima treba shvatiti samo kao pokušaj, a nikako kao definitivno opredeljenje.

19 Stern 1975, 25, br. 8, 16, 23 i 69.

20 Цветковић-Томашевић 1981, 183.

21 Цветковић-Томашевић 1981, 185.

22 Тапавички 1998, 124. 


\section{LITERATURA}

\section{Марковић 1952}

Марковић M., Ad CIL III 8153 (Singidu-

num), Жива антика 2, Скопље 1952, 234-240.

\section{Picard, Stierlin 1988}

Picard G., Stierlin H. (izdavač), Architektur der Welt-Imperium Romanum, Berlin 1988.

\section{Stern 1975}

Stern H., Recueil général des mosaïques de la Gaule I - Gaule Belgique - 1. Partie Ouest, Paris 1975.

\section{Тапавички 1998}

Тапавички М., Неки од резултата нај-новијих ископавања у Београду, улица Косанчићев венац 12-16, Гласник САД 14, Београд 1998, 119-126.

\section{Тапавички 1998а}

Тапавички М., Нови налази римског новца са ископавања на локалитету Косанчићев венац 12-16 у Београду, Нумизматичар 21, Београд 1998, 54-62.

\section{Цветковић-Томашевић 1981}

Цветковић-Томашевић Г., Археолошки локалитет на Косанчићевом венцу бр. 12-16 у Београду, Саопштења XIII, Београд 1981, 177-197.

\section{A CONTRIBUTION TO THE STUDY OF ROMAN ARCITECTURAL REMAINS ON THE SITE 12-16 KOSANČIĆEV VENAC STREET IN BELGRADE}

During the excavation in 12-16 Kosančićev venac Street in Belgrade, remains of a building from Roman times were discovered. Considering the fact that only the central part of the building was excavated, it was difficult to determine its purpose. Nevertheless, in the vicinity of this site, within the yard of the Patriarchate, an inscription was found, on which a Roman public bath, the thermae, is mentioned. They were errected by Elius Tercius, who built them for his fellow-soldiers from the legion 4th Flavia. The decription of the bath built by this veteran is given on the inscription. In many details, it corresponde to the results gained during the excavation (pool, mosaics etc.). Therefore, one can presume that on the mentioned site, there actually was a Roman bath, used during 3rd and 4th century A.D. 


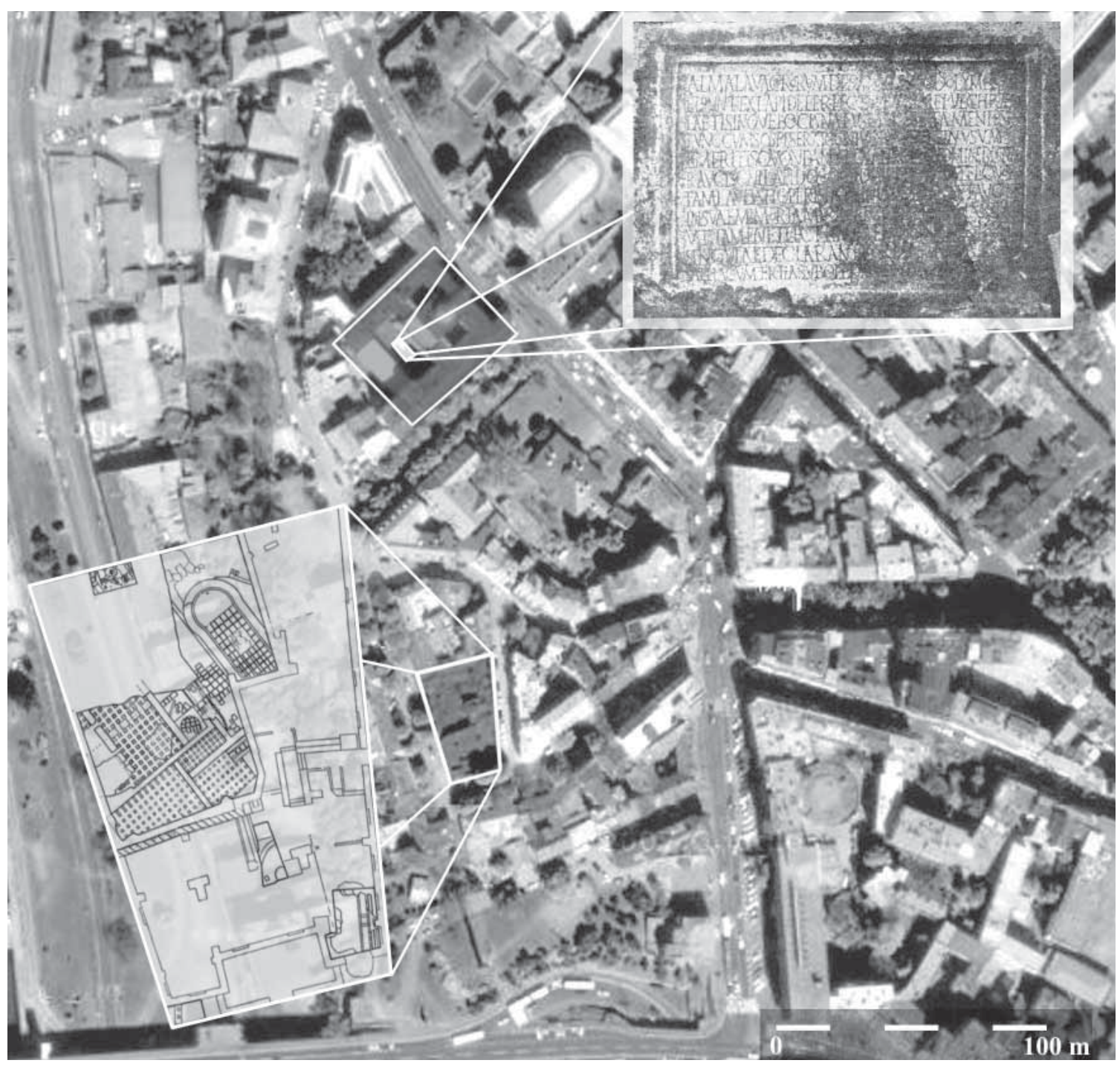

Položaj rimskih građevinskih ostataka na lokalitetu Kosančićev venac 12-16 u Beogradu u odnosu na mesto nalaza natpisa u dvorištu zgrade Patrijaršije. 